\title{
ANALISIS PERSEPSI APARATUR PEMERINTAH DESA TERHADAP DANA DESA DI KECAMATAN TALANG EMPAT KABUPATEN BENGKULU TENGAH
}

\author{
Meiyudi Ardianto, Neri Susanti \\ Program Studi Akuntansi Fakultas Ekonomi Universitas Dehasen Bengkulu \\ nerrysusanti@yahoo.com
}

\begin{abstract}
ABSTRAK
Meiyudi Ardianto, Neri Susanti; Penelitian ini bertujuan untuk mendapatkan persepsi aparat desa untuk menggunakan dana desa, penggunaan dana desa sesuai SK Menteri Nomor 08 tahun 2016. Penelitian dilakukan di Kabupaten Talang Empat Kabupaten Bengkulu Tengah dengan jumlah desa sebanyak 15 desa. Penelitian ini menggunakan metode analisis skala penilaian dengan menggunakan kuesioner yang disebarkan di setiap desa dan berhadapan langsung dengan aparat pemerintah desa.

Hasil penelitian menunjukkan variabel organisasi pemerintah desa memperoleh nilai 718, variabel pelaksanaan pembangunan pedesaan memperoleh nilai 706 sedangkan variabel pemberdayaan dan pengembangan masyarakat memperoleh nilai 690 dan masyarakat pedesaan dengan nilai 713 ini. Artinya aparat desa sangat setuju dengan kegiatan tersebut. Oleh karena itu, persepsi aparat pemerintah desa sesuai dengan anggaran pemerintah desa. Namun faktanya, aparat pemerintah desa tidak sepenuhnya mengerti tentang penggunaan dana desa. Hal ini karena variabel pelaksanaan pemerintahan desa dan pembangunan masyarakat pedesaan tidak menggunakan dana desa
\end{abstract}

\begin{abstract}
Meiyudi Ardianto, Neri Susanti; This study aimed to get the perception of the village apparatus to use village funds, the use of the village funds according to the ministerial decree of village No. 08 year of 2016. The study was conducted in Talang Empat district of Central Bengkulu regency with a number of villages as many as 15 villages. This study was used rating scale analysis method by means of questionnaires distributed in each village and direct face with the village government apparatus.

The results of the study show the village government organization variable gain the value of 718, variable of the implementation of rural development gain the value of 706 while the community empowerment and development variable gain the value of 690 and rural communities with a value of 713 this means the village government apparatus strongly agreed with these activities. Therefore, the perception of the village government apparatus in accordance with the village government budget. But in fact, the village government apparatus do not fully understand about the use of village funds. This is because the variable of the implementation of the village government and development of rural communities do not use the village funds
\end{abstract}

Key Words: The village government apparatus, the village funds.

\section{LATAR BELAKANG}

Di dalam sistem pemerintahan, pemerintah daerah diberi hak untuk membuat dan menetapkan peraturan-peraturan. Peraturan-peraturan tersebut dibuat dengan tujuan agar masyarakat memiliki pedoman dalam bermasyarakat sehingga keadaan yang tak diinginkan tidak terjadi. Dengan adanya peraturan ini maka sistem pemerintahan lebih mudah utuk melaksanakan otonomi daerah. Berdasarkan Undang-Undang Nomor 32 Tahun 2004 tentang pemerintah daerah otonomi daerah adalah hak, wewenang dan kewajiban daerah otonom untuk mengatur serta mengurus pemerintahan dan kepentingan masyarakat setempat dan sesuai dengan peraturan perundang-undangan. Dari pengertian tersebut dapat disimpulkan bahwa otonomi daerah yaitu wilayah atau daerah tertentu yang diberikan hak, kewajiban dan kewenangan untuk mengatur serta mengurus daerahnya tanpa melanggar peraturan perundang-undangan. Secara garis besar, dengan adanya otonomi daerah ini membuat pemerintahan lebih mudah untuk menjalankan tugas dan kewajibannya.

Pada dasarnya desa merupakan salah satu dari otonomi daerah, dimana daerah merupakan pembagian dari wilayah administratif di Indonesia di bawah kecamatan yang dipimpin oleh Kepala Desa yang dibantu oleh aparatur desa yang lain. Keberadaan desa tercantum dalam Peraturan Pemerintah Nomor 72 Tahun 2005 tentang Desa. Berdasarkan peraturan pemerintah tersebut desa adalah kesatuan masyarakat hukum yang memiliki batas-batas wilayah yang berwenang untuk mengatur dan mengurus kepentingan masyarakat setempat, berdasarkan asal-usul dan adat istiadat setempat yang diakui dan 
dihormati dalam sistem Pemerintahan Negara Kesatuan Republik Indonesia. Dengan pengertian ini desa merupakan suatu organisasi pemerintah yang secara politis memiliki kewenangan untuk mengurus dan mengatur warganya dengan tidak menghilangkan rasa kekeluargaan dan adat istiadat. Dari keadaan tersebut menempatkan desa sebagai salah satu indikator penunjang keberhasilan pemerintahan. Sehingga sangatlah logis jika pembangunan desa menjadi prioritas utama bagi pemerintah untuk mensukseskan pembangunan nasional.

Namun untuk melakukan pembangunan tersebut dibutuhkan dana yang tidak kecil sehingga diperlukan kewenangan dan tuntutan tersedianya dana yang cukup. Pembiayaan merupakan faktor terpenting dalam proses dan penyelenggaraan pembangunan daerah, maka untuk mengatur dan mengurus rumah tangga sendiri desa memerlukan dukungan dari pemerintah melalui dana yang memadai. Oleh karena itu, untuk menunjang pendanaan tersebut pemerintah memberikan kebijakan bahwa setiap desa diberikan dana dengan tujuan agar tidak terjadi ketimpangan antara masyarakat kota dengan desa serta mampu menekan angka kemiskinan. Pembiayaan tersebut dimulai pada tahun 2014 hal ini merupakan nawacita yang dicanangkan oleh pemerintahan saat ini. Untuk dapat mencapai pembangunan nasional maka harus dimulai dari bawah yaitu desa. Oleh karena itu, dikeluarkan peraturan pemerintah (PP) tahn 2014 tentang dana desa yang bersumber dari Angaran Pendapatan Belanja Negara (APBN). Dana yang diberikan pemerintah tersebut dikenal dengan Dana Desa. Dana desa merupakan dana yang diberikan oleh pemerintah pusat kepada desa yang diperuntukan bagi desa untuk membiayai penyelenggaraan pemerintahan, pelaksanaan pembangunan, pembinaan kemasyarakatan dan pemberdayaan masyarakat.

Kecamatan Talang Empat merupakan salah satu dari Kecamatan yang terdapat di Kabupaten Bengkulu Tengah yang memiliki jumlah desa sebanyak tiga belas desa dimana desa ini turut mendapatkan dana desa dari pemerintah pusat. Dari tahun 2014 Kecamatan Talang Empat telah mengalokasikan dana untuk desa yang masyarakat kenal dengan istilah Dana Desa, dengan harapan pembangunan infrastruktur semakin baik dan merata sehingga tidak terjadi kecemburuan sosial di tengah masyarakat. Akan tetapi karena belum diimbangi dan minimnya pengetahuan tentang dana desa tersebut, menyebabkan dana yang harusnya bisa dimanfaatkan semaksimal mungkin sebagai modal untuk membangun perdesaan yang jauh lebih baik dan dapat membawa kesejahteraan bagi masyarakatnya tidak dapat terealisasikan dengan baik. Kurangnya pengetahuan terhadap dana desa ini harusnya dapat dituntaskan dengan adanya penyuluhan terhadap aparatur desa mengenai engelolaan dan penggunaan dana desa. Sehingga diharapkan dengan adanya penyuluhan tersebut dapat memberikan pencerahan terhadap pihak aparatur desa dalam melakukan pengelolaan dan penggunaan dana desa tersebut. Selain itu, aparatur desa juga memerlukan tim pendamping. Dimana tugas tim pendamping membantu aparatur desa dalam mengelola dana desa tersebut sehingga pembangunan dan pemberdayaan yang dilakukan tidak berbeda dengan rencana yang telah ditetapkan oleh pemerintah. Dana desa yang diberikan oleh pemerintah kepada desa memiliki nominal yang lumayan besar. Oleh karena itu, dengan jumlah besaran dana desa yang dikucurkan cukup besar, maka diperlukan monitoring dan evaluasi terhadap pengelolaan dan penggunaan dana desa. Pengawasan tersebut bertujuan agar tidak adanya praktik-praktik yang menyimpang didalam pengelolaan dan penggunaan dana desa. Selain adanya pengawasan diperlukan juga sikap yang jujur kepada aparatur pemerintah desa dalam mengelola dan menggunakan dana desa. Karena tanpa adanya kejujuran akan sangat mudah melakukan praktik-praktik kecurangan yang dapat merugikan bagi desa itu sendiri. Dengan adanya pengawasan dan kesadaran diri untuk memajukan desa oleh aparatur desa diharapkan dampak pembangunan dan pemberdayaan terhadap masyarakat dapat segera dirasakan serta perkembangan dan dan kemajuan terhadap infrastruktur dapat dimanfaatkan dengan sebaik mungkin oleh masyarakat setempat. Sehingga dengan keadaaan ini akan membawa desa dan masyarakat desa sejahtera serta keinginan dan harapan dari pemerintah ikut sukses.

Dengan keadaan tersebut memberikan alasan kepada penulis dalam memilih program Dana Desa yang di programkan oleh pemerintah. Ketertarikan ini dikarenakan program Dana Desa memiliki implikasi yang sangat signifikan terhadap kemajuan dan perkembangan terhadap pembangunan desa yang ada di Kecamatan Talang Empat Kabupaten Bengkulu Tengah. Pengendalian dalam program dana desa ini ditangani oleh aparatur desa dan masyarakat setempat. Akan tetapi terkadang aparatur dan masyarakat sendiri kurang memahami bagaimana penggunaan dana yang baik. Hal ini dikarenakan kurangnya sosialisasi yang membuat aparatur desa dan masyarakat sulit untuk mengerti maksud dan tujuan terhadap dana tersebut. Sehingga terkadang dalam praktiknya didalam pengelolaan dan penggunaan dana desa tersebut sering kali terjadi kecurangan dan penyimpangan dalam pemanfaatan dana sehingga harapan dan realisasi berbanding terbalik. 


\section{LANDASAN TEORI}

\section{Persepsi}

Secara umum persepsi adalah proses mengamati dunia luar yang mencakup perhatian, pemahaman, dan pengenalan objek-objek atau peristiwa. Biasanya persepsi diorganisasikan kedalam bentuk (figure), dasar (ground), garis bentuk (garis luar, kontur), dan kejelasan. Dalam arti sempit persepsi merupakan penglihatan, bagaimana cara seseorang memelihat sesuatu, sedangkan dalam arti luas ialah pandangan atau pengertian, yaitu bagaimana seseorang memandang atau mengartikan sesuatu.

Menurut jalaludin (2007:51) persepsi adalah pengalaman tentang objek, peristiwa, atau hubungan yang diperoleh dengan menyimpulkan informasi dan menafsirkan pesan. Persepsi ini memberikan makna pada stimulasi inderawi. Sedangkan Persepsi menurut Kamus Besar Bahasa Indonesia (2007) adalah sebagai tanggapan (penerimaan) langsung dari sesuatu atau merupakan proses seseorang mengetahui beberapa hal yang dialami oleh setiap informasi tentang lingkungan melalui panca indera.

Dari beberapa pendapat tersebut dapat disimpulkan persepsi adalah suatu proses dalam mengamati dan memahami objek sehingga mampu menarik kesimpulan dari objek yang diamati dan diperhatikan.

Di dalam buku pengantar psikologi dalam keperawatan menurut Herri dan Namara (2010:40) menjelaskan ada beberapa faktor yang mempengaruhi seseorang berpersepsi diantaranya yaitu:

1. Minat, artinya semakin tinggi minat seseorang terhadap suatu objek atau peristiwa, maka semakin tinggi juga minatnya dalam memersepsikan objek atau peristiwa.

2. Kepentingan, artinya semakin dirasakan penting terhadap suatu objek atau peristiwa tersebut bagi diri seseorang, maka semakin peka dia terhadap objek-objek persepsinya.

3. Kebiasaan, artinya objek atau peristiwa semakin sering dirasakan seseorang, maka semakin terasa dirinya di dalam membentuk persepsi.

4. Konstansi, artinya adanya kecenderungan seseorang untuk selalu melihat objek atau kejadian secara konstan sekalipun sebenarnya itu bervariasi dalam bentuk, ukuran, warna, dan kecemerlangan.

Didalam proses mengamati dan memahami suatu objek sehingga dapat meyimpulkan dari objek yang diamati dan dipahami terdapat tiga bentuk persepsi. Menurut Herri dan Namora (2010:40) Bentukbentuk persepsi tersebut adalalah sebagai berikut:

a. Persepsi Jarak

Persepsi ini cenderung dianggap sebagai apa yang dihayati oleh indra perorangan yang berkaitan dengan bayangan dua dimensi. Sehingga ditemukan bahwa stimulus visual memiliki ciri-ciri yang berhubungan dengan jarak pengamatan. Atau yang lebih dikenal dengan istilah isyarat jarak (distance cues).

b. Persepsi Gerakan

Persepsi ini memiliki isyarat persepsi gerakan ada di lingkungan sekitar manusia. Teori Gibson dkk mengatakan bahwa ketika kita melihat suatu benda bergerak ada sebagian menutupi dan sebagian lagi tidak menutupi latar belakangnya yang tidak bergerak. Jika tidak peduli dengan pandangan apa yang kita ikuti maka ada isyarat yang kita tinggalkan sehingga dapat memungkinkan terjadinya kekeliruan dalam memersepsikan.

c. Persepsi Kedalaman

Persepsi ini memungkinkan munculnya penggunaan isyarat-isyarat fisik, seperti akomodasi, konvergensi dan disparatis selaput jala dari mata yang disebabkan oleh persefktif linier dan udara dimana ukuran relatif dari objek dalam penjajaran, bayangan, ketinggian tekstur, atau susunan.

\section{Dana Desa}

Dalam Peraturan Pemerintah (PP) No 60 Tahun 2014 Bab 1 Pasal 1 menjelaskan bahwa Dana Desa adalah dana yang bersumber dari Anggaran Pendapatan Belanja Negara (APBN) yang diperuntukan bagi desa, yang ditransfer melalui aggaran belanja daerah/kabupaten. Dana ini digunakan untuk membiayai kegiatan penyelenggaraan pemerintahan, pelaksanaan pembangunan, pembinaan masyarakat dan pemberdayaan masyarakat. Anggaran Pendapatan Belanja Negara (APBN) adalah rencana tahunan keuangan tahunan pemerintahan negara yang disetujui Oleh Dewan Perwakilan Rakyat (DPR). Dari penjelasan diatas dana desa merupakan dana yang diberikan oleh pemerintah pusat kepada desa untuk dijadikan sebagai biaya dalam bidang pembangunan dan pemberdayaan masyarakat. Dana desa merupakan pendapatan asli daerah (PADesa) dengan jenis pendapatan transfer desa.

Dana desa dialokasikan oleh pemerintah untuk desa dengan harapan sesuai dengan nawacita Presiden bahwa pembangunan negara dimulai dari yang paling bawah yaitu desa. Dana desa ini digunakan untuk membiayai penyelenggaraan pemerintah, pembangunan, pemberdayaan masyarakat, dan kemasyarakatan. Penggunaan dana desa ini mengacu kepada pembangunan jangka menengah desa 
dan rencana kerja pemerintah desa. Besaran alokasi anggaran yang peruntukannya langsung ke Desa ditentukan 10\% (sepuluh perseratus) dari dan di luar dana Transfer Daerah (on top) secara bertahap. Anggaran yang bersumber dari APBN dihitung berdasarkan jumlah desa dan dialokasikan dengan memperhatikan jumlah penduduk, angka kemiskinan, luas wilayah, dan tingkat kesulitan geografis dalam rangka meningkatkan kesejahteraan dan pemerataan pembangunan Desa. Besaran dana desa yang diberikan kepada desa ditetapkan oleh bupati masing-masing desa.

\section{Penggunaan Dana Desa}

Dana desa diperuntukan sebagai pembiayaan kepada desa untuk meningkatkan dan mengembangkan sarana dan prasarana yang ada. Sehingga dengan adanya dana desa ini diharapkan agar desa tidak ada yang tertinggal dan tidak terjadi kesenjangan sosial didalam masyarakat. Dana yang diberikan oleh pemerintah pusat hendaknya digunakan untuk membangun hal-hal yang diperlukan oleh masyarakar dalam mendukung kegiatan masyarakat dengan harapan mampu meningkatkan pendapatan serta kegiatan yang bersifat membina untuk mensejahterahkan masyarakat. Oleh karena itu maka harus sesuai dengan peraturan Permendagri No 113 dan 114 tentang Pengelolaan dan Penggunaan dana desa. Pengunaan Dana Desa ditujukan untuk membiayai penyelenggaran pemerintah daerah yang diprioritaskan untuk pembangunan dan pemberdayaan serta pembinaan masyarakat. Penetapan prioritas penggunaan dana desa dilakukan setelah berkoordinasi dengan menteri yang menyelenggarakan urusan pemerintahan di bidang perencanaan pembangunan nasional yang dilengkapi dengan pedoman umum pelaksanaan pengunaan dana desa. Sebelum menggunakan dana desa terlebih dahulu melihat perencaan pembangunan desa. Perencanaan pembangunan desa memiliki jangka waktu yang berbeda-beda yang mana pembangunan tersebut meliputi rencana pembangunan jangka menengah dan rencana pembangunan tahunan desa. Penyelenggaran pemerintahan desa berdasarkan atas beberapa asas yaitu :

a. Kepastian hukum yaitu asas dalam negara hukum yang mengutamakan landasan peraturan perundang-undangan, kepatutan, dan keadilan dalam setiap kebijakan penyelenggaraan pemerintahan desa.

b. Tertib penyelenggaraan pemerintahan adalah asas yang menjadi landasan keteraturan, keserasian, dan keseimbangan dalam pengendalian penyelenggara pemerintahan desa.

c. Tertib kepentingan umum yaitu asas yang mendahulukan kesejahteraan umum dengan cara yang aspiratif, akomodatif, dan selektif.

d. Keterbukaan yaitu asas yang membuka diri terhadap hak masyarakat untuk memperoleh informasi yang benar, jujur, dan tidak diskriminatif tentang penyelenggaraan pemerintahan desa dengan tetap memperhatikan ketentuan peraturan peraturan perundang-undangan.

e. Proporsionalitas; yaitu asas yang mengutamakan keseimbangan antara hak dan kewajiban penyelenggaraan pemerintahan desa.

f. Profesionalitas yaitu asas yang mengutamakan keahlian yang berlandaskan kode etik dan ketentuan peraturan perundang-undangan.

g. Akuntabilitas, yaitu asas yang menentukan bahwa setiap kegiatan dan hasil akhir kegiatan penyelenggaraan pemerintahan desa harus dapat dipertanggungjawabkan kepada masyarakat desa sesuai peraturan perundang-undangan.

h. Efektivitas dan efisiensi. Efektif berarti setiap kegiatan yang dilaksanakan harus berhasil mencapai tujuan yang diinginkan masyarakat desa. Efisien berarti setiap kegiatan yang dilaksanakan harus tepat sesuai dengan rencana dan tujuan.

i. Kearifan lokal; mengandung arti bahwa dalam penetapan kebijakan harus memperhatikan kebutuhan dan kepentingan masyarakat desa.

j. Keberagaman; berarti penyelenggaraan pemerintahan desa tidak boleh mendiskriminasi kelompok tertentu.

k. Partisipatif berarti penyelenggaraan pemerintahan desa mengikut sertakan kelembagaan desa dan unsur masyarakat desa.

Selain itu pembinaan masyarakat juga merupakan prioritas dari penggunaan dana desa. Peraturan Pemeritah (PP) 72 tahun 2005 adalah pemberian pedoman, standar pelaksanaan, perencanaan, penelitian, pengembangan, bimbingan, pendidikan dan pelatihan, konsultasi, supervisi, monitoring, pengawasan umum dan evaluasi pelaksanaan penyelenggaraan pemerintahan desa. Pembinaan terhadap masyarakat bertujuan untuk memberikan bimbingan dan arahan kepada masyarakat guna meningkatkan kesejahteraan baik dari segi pendidikan, kesehatan, agama maupun budaya. Sedangkan pemberdayaan masyarakat desa menurut Undang-Undang Nomor 6 tahun 2014 Pasal 1 Nomor 12 adalah upaya 
mengembangkan kemandirian dan kesejahteraan masyarakat dengan meningkatkan pengetahuan, sikap, keterampilan, perilaku, kemampuan, kesadaran, serta memanfaatkan sumberdaya melalui penetapan kebijakan, program, kegiatan, dan pendampingan yang sesuai dengan esensi masalah prioritas kebutuhan masyarakat Desa. Pemberdayaan masyarakat sangatlah diperlukan hal ini di karenakan untuk tercapainya kesejahteraan bagi masyarakat desa. Namun dalam melakukan pemberdayaan tersebut nilainilai budaya jangan dihilangkan. Pemberdayaan masayarakat atau community-development memiliki tujuan untuk melakukan pembangunan pada masyarakat dari beberapa segi aspek yang terdapat pada masayarakat itu sendiri. Adapun aspek tersebut yaitu ekonomi, sosial dan budaya, kesehatan dan pendidikan.

Agar tidak terjadi penyalahgunaan dana dan kekuasaan didalam pengalokiasian, penyaluran dan penggunaan dana desa tersebut maka diperlukan tim pendamping. Tim pendamping bertugas untuk memberikan arahan dan masukan kepada aparatur desa dalam hal kegiatan ataupun pembangunan yang harus dilakukan serta pembukuan yang baik dan benar. Sedangkan tim pengawas berperan dalam mengawasi penggunaan dana dengan harapan mampu meperkecil praktik penyimpangan. Pada tingkatan desa kepala desa merupakan pelaksana yang bertanggungjawab terhadap penggunaan dana desa serta keberhasilan pelaksanaan pembangunan dan perkembangan desa. Sehingga peran kepala desa didalam dana desa ini sangat fital, untuk itu diperlukannya arahan dan masukan dari tim pendamping.

\section{Dasar Hukum Dana Desa}

Pada dasarnya setiap kegiatan yang pendanaannya dibiayai oleh pemerintah selalu memiliki dasar hukum, begitu pula terhadap dana desa. Undang-undang No 06 Tahun 2014 mengatur tentang desa yang mana diperjelas kemmbali melalui Peraturan Pemerintah (PP) No 602014 tentang dana desa yang bersumber dari Anggaran Pendapatan Belanja Negara (APBN). Namun pada tahun 2015 peraturan pemerintah tersebut diubah menurut Peraturan Pemerintah (PP) No 22 tahun 2015 Tentang Perubahan Atas PP No 60 tahun 2014. Selain itu dana desa memiliki peraturan yang lain yaitu :

1. PMK Nomor 257/PMK.07/2015 Tentang Tata Cara Penundaan Dan/Atau Pemotongan Dana Perimbangan Terhadap Daerah Yang Tidak Memenuhi Add.

2. PMK Nomor 49/PMK.07.2016 Tentang Tata Cara Pengalokasian, Penyaluran, Penggunaan, Pemantauan Dan Evaluasi Desa.

3. Permendes No. 21/2015 Tentang Prioritas Penggunaan Dana Desa Tahun 2016.

4. Pemendagri No. 113/2014 Tentang Pengelolaan Keuangan Desa.

5. Permendes No. 08/2016 Tentang Perubahan Atas Peraturan Menteri Desa, Pembangunan Daerah Tertinggal, Dan Transmigrasi Nomor 21 Tahun 2015 Tentang Penetapan Prioritas Penggunaan Dana Desa Tahun 2016.

\section{KERANGKA ANALISIS}

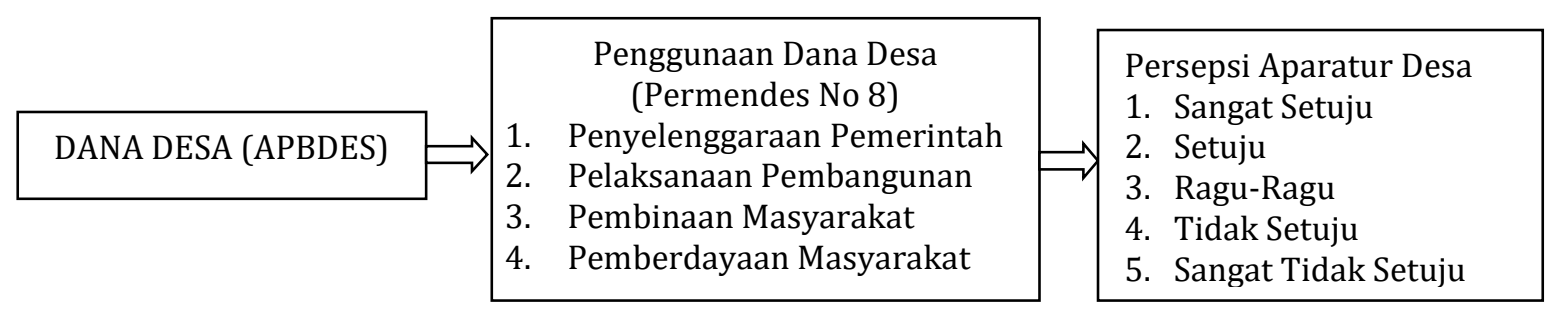

Gambar 1. Kerangka Analisis

\section{METODOLOGI}

Pada penelitian ini metode yang digunakan yaitu metode penilitian Kualitatif. Populasi aparatur pemerintah disetiap desa terdapat dua (2) orang aparatur desa dimana aparatur desa tersebut merupakan perangkat desa serta desa yang ada di Kecamatan Talang Empat Kabupaten Bengkulu Tengah berjumlah 15 desa. Dari penjelasan tersebut maka populasi berjumlah 30 orang. Pertimbangan yang menjadi syarat didalam penelitian ini yaitu aparatur pemerintah desa yang terdiri dari kepala desa dan bendahara desa di Kecamatan Talang Empat Kabupaten Bengkulu Tengah yang memiliki keterkaitan terhadap dana desa. Dimana terdapat tiga belas (15) desa dengan mengambil sampel dari setiap desa sebanyak dua (2) orang sehingga jumlah responden sebanyak 30 orang. Metode pengumpulan data di dalam penelitian ini digunakan untuk mendapatkan data yang akurat, aktual dan relevan. Metode pengumpulan data menggunakan Kuesioer (angket). 
HASIL PENELITIAN DAN PEMBAHASAN

Deskripsi Persepsi Aparatur Pemerintah Desa Terhadap Dana Desa Di Kecamatan Talang Empat Kabupaten Bengkulu Tengah

Setelah melakukan penelitian kepada aparatur pemerintah desa di Kecamatan Talang Empat Kabupaten Bengkulu Tengah, maka didapat tanggapan responden melalui kuesioner yang meliputi 4 item pernyataan dengan 5 buah pertanyaan di setiap pernyataan. Adapun tanggapan dari responden dapat dilihat dan dijabrkan dalam tabel berikut ini.

\section{Penyelenggaraan Pemerintah Desa}

Tabel 1. Persepsi Responden Terhadap Penyelenggaraan Pemerintah Desa

\begin{tabular}{|c|c|c|c|c|c|c|c|c|}
\hline \multirow{2}{*}{ No } & \multirow{2}{*}{ Pernyataan } & \multicolumn{5}{|c|}{ Tanggapan Responden } & \multirow{2}{*}{$\begin{array}{l}\text { Jumlah } \\
\text { Skor }\end{array}$} & \multirow{2}{*}{$\begin{array}{l}\text { Rata- } \\
\text { rata }\end{array}$} \\
\hline & & SS & $\mathrm{S}$ & $\overline{\mathbf{R}}$ & TS & STS & & \\
\hline 1. & $\begin{array}{l}\text { Dalam penyelenggaraan Pemerintah desa harus } \\
\text { bersikap terbuka terhadap masyarakat }\end{array}$ & 29 & 1 & 0 & 0 & 0 & 149 & 4,97 \\
\hline 2. & $\begin{array}{l}\text { Pemerintah desa harus bersikap profesionalitas } \\
\text { berlandaskan kode etik }\end{array}$ & 29 & 1 & 0 & 0 & 0 & 149 & 4,97 \\
\hline 3. & $\begin{array}{l}\text { Setiap kegiatan harus berdasarkan pada efektivitas } \\
\text { dan efesiensi }\end{array}$ & 21 & 9 & 0 & 0 & 0 & 141 & 4,7 \\
\hline 4. & $\begin{array}{l}\text { Penyelenggaraan pemerintah desa } \\
\text { mengikutsertakan masyarakat }\end{array}$ & 22 & 7 & 1 & 0 & 0 & 141 & 4,7 \\
\hline 5. & $\begin{array}{l}\text { Dalam penyelenggaraan pemerintah desa harus } \\
\text { berasaskan pada tertib penyelenggaraan } \\
\text { pemerintah }\end{array}$ & 19 & 10 & 1 & 0 & 0 & 138 & 4,6 \\
\hline & Jumlah & 120 & 28 & 2 & 0 & 0 & 718 & 23,94 \\
\hline
\end{tabular}

Sumber : Hasil Kuesioner dan Diolah, 2016

Dari Tabel 1 diatas dapat diketahui bahwa jumlah skor jawaban yang diberikan oleh aparatur pemerintah desa terhadap penyelenggaraan pemerintah desa sebesar 718 atau nilai rata-rata 23,94. Hal ini menempatkan penyelenggaraan pemerintah desa berada pada interval kelas 631 - 750 atau Sangat Setuju. Sehingga dari penjelasan tersebut dapat digambarkan grafik kontimum seperti pada gambar berikut ini :

Gambar 1. Grafik Penyelenggaraan Pemerintah Desa

\begin{tabular}{r|r|r|r|r|r|} 
& $\begin{array}{c}\text { Sangat Tidak } \\
\text { Setuju }\end{array}$ & Tidak Setuju & Ragu-ragu & Setuju & $\begin{array}{c}\text { Sangat } \\
\text { Setuju }\end{array}$ \\
\cline { 2 - 6 } & & & & & 718 \\
750
\end{tabular}

Berdasarkan dari tabel 1. dan gambar 1. dapat diketahui bahwa rating scale jawaban untuk variabel penyelenggaraan pemerintah desa sebesar 718. Hal ini berarti penyelenggaraan pemerintah desa berada pada interval kelas 631-750 (SS), sehingga menunjukkan aparatur pemerintah desa di Kecamatan Talang Empat Kabupaten Bengkulu Tengah belum memahami dan mengerti dalam menggunakan dana desa.

\section{Pembangunan Desa}

Tabel 2. Persepsi Responden Terhadap Pembangunan Desa

\begin{tabular}{|c|c|c|c|c|c|c|c|c|}
\hline \multirow{2}{*}{ No } & \multirow{2}{*}{ Pernyataan } & \multicolumn{5}{|c|}{ Tanggapan Responden } & \multirow{2}{*}{$\begin{array}{l}\text { Jumlah } \\
\text { Skor }\end{array}$} & \multirow{2}{*}{$\begin{array}{l}\text { Rata- } \\
\text { rata }\end{array}$} \\
\hline & & SS & S & $\overline{\mathbf{R}}$ & TS & STS & & \\
\hline 1. & $\begin{array}{lll}\text { Pembangunan dilaksanakan } & \text { sesuai dengan } \\
\text { Rencana Kerja Pemerintah Desa } & & \\
\end{array}$ & 27 & 3 & 0 & 0 & 0 & 147 & 4,9 \\
\hline 2. & Pembangunan melibatkan masyarakat & 27 & 3 & 0 & 0 & 0 & 147 & 4,9 \\
\hline 3. & $\begin{array}{l}\text { Pelaksanaan pembangunan menggunakan sumber } \\
\text { daya alam yang ada di desa }\end{array}$ & 14 & 14 & 0 & 1 & 1 & 129 & 4,3 \\
\hline 4. & $\begin{array}{l}\text { Pembangunan berskala lokal dilaksanakan oleh } \\
\text { desa }\end{array}$ & 22 & 8 & 0 & 0 & 0 & 142 & 4,73 \\
\hline 5. & $\begin{array}{l}\text { Pelaksanaan yang ada di program sektoral } \\
\text { haruslah terintegrasi } \\
\text { dengan pembangunan desa }\end{array}$ & 21 & 9 & 0 & 0 & 0 & 141 & 4,7 \\
\hline & Jumlah & 111 & 37 & 0 & 1 & 1 & 706 & 23,53 \\
\hline
\end{tabular}

Sumber : Hasil Kuesioner dan Diolah, 2016 
Dari Tabel 2 diatas dapat diketahui bahwa jumlah skor jawaban yang diberikan oleh aparatur pemerintah desa terhadap pembangunan desa sebesar 706 atau nilai rata-rata 23,53. Hal ini menempatkan pemabngunan desa berada pada interval kelas 631 - 750 atau Sangat Setuju. Sehingga dari penjelasan tersebut dapat digambarkan grafik kontimum seperti pada gambar berikut ini :

Gambar 2. Grafik Pembangunan Desa

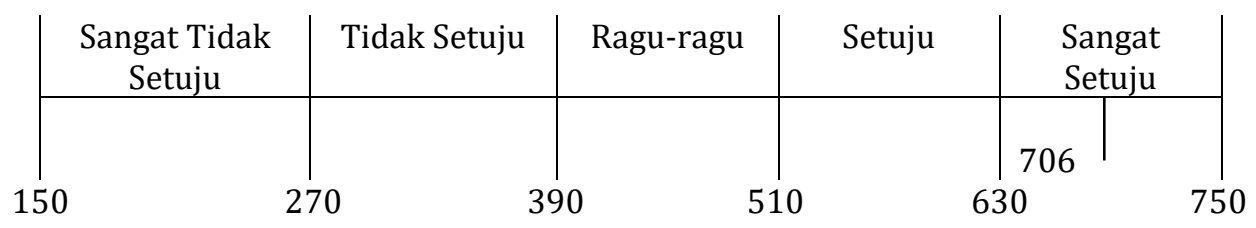

Berdasarkan dari tabel 2. dan gambar 2. dapat diketahui bahwa rating scale jawaban untuk variabel pembangunan desa yaitu sebesar 706. Hal ini berarti pembangunan desa berada pada interval kelas 630750 atau Sangat Setuju (SS), sehingga menunjukkan bahwa faktor pembangunan desa merupakan faktor yang dominan dalam mempengaruhi persepsi atau sikap dari aparatur pemerintah desa terhadap penggunaan dana desa di Kecamatan Talang Empat Kabupaten Bengkulu Tengah. Sehingga aparatur pemerintah desa telah memahami penggunaan dana desa.

\section{Pemberdayaan Masyarakat Desa}

Tabel 3. Persepsi Responden Terhadap Pemberdayaan Masyarakat Desa

\begin{tabular}{|c|c|c|c|c|c|c|c|c|}
\hline \multirow{2}{*}{ No } & \multirow{2}{*}{ Pernyataan } & \multicolumn{5}{|c|}{ Tanggapan Responden } & \multirow{2}{*}{$\begin{array}{l}\text { Jumlah } \\
\text { Skor }\end{array}$} & \multirow{2}{*}{$\begin{array}{l}\text { Rata- } \\
\text { rata }\end{array}$} \\
\hline & & SS & $S$ & $\mathrm{R}$ & TS & STS & & \\
\hline 1. & $\begin{array}{l}\text { Pemberdayaan masyarakat desa bertujuan untuk } \\
\text { mensejahterahkan masyarakat }\end{array}$ & 27 & 3 & 0 & 0 & 0 & 147 & 4,9 \\
\hline 2. & $\begin{array}{llll}\text { Dalam pemberdayaan } & \text { masyarakat desa di } \\
\text { perlukan pendampingan } & & & \\
\end{array}$ & 20 & 10 & 0 & 0 & 0 & 140 & 4,67 \\
\hline 3. & $\begin{array}{l}\text { Dalam pemberdayaan masyarakat desa tidak } \\
\text { menghilangkan nilai budaya }\end{array}$ & 22 & 8 & 0 & 0 & 0 & 142 & 4,73 \\
\hline 4. & $\begin{array}{l}\text { Peran pendamping semakin lama semakin } \\
\text { sedikitagar masyarakat mampu mandiri }\end{array}$ & 14 & 13 & 2 & 1 & 0 & 130 & 4,33 \\
\hline 5. & $\begin{array}{l}\text { Dalam Fasilitator berisi masyarakat, lembaga- } \\
\text { lembaga yang dinaungi oleh pelaku program } \\
\text { permberdayaan masyarakat }\end{array}$ & 12 & 17 & 1 & 0 & 0 & 131 & 4,37 \\
\hline & Jumlah & 95 & 51 & 3 & 1 & 0 & 690 & 23 \\
\hline
\end{tabular}

\section{Sumber : Hasil Kuesioner dan Diolah, 2016}

Dari Tabel 3 diatas dapat diketahui bahwa jumlah skor jawaban yang diberikan oleh aparatur pemerintah desa terhadap pemberdayaan masyarakat desa sebesar 690 atau nilai rata-rata 23. Hal ini menempatkan pemberdayaan masyarakat desa berada pada interval kelas 631 - 750 atau Sangat Setuju. Sehingga dari penjelasan tersebut dapat digambarkan grafik kontimum seperti pada gambar berikut ini :

Gambar 3. Grafik Pemberdayaan Masyarakat Desa

\begin{tabular}{|c|c|c|c|c|c|}
\hline $\begin{array}{l}\text { Sangat } \\
\text { Setuju }\end{array}$ & Tidak & Tidak Setuju & Ragu-ragu & Setuju & $\begin{array}{l}\text { Sangt } \\
\text { Setuju }\end{array}$ \\
\hline & & & & & 690 \\
\hline
\end{tabular}

Berdasarkan dari tabel 3. dan gambar 3. dapat diketahui bahwa rating scale jawaban untuk variabel pemberdayaan masyrakat desa sebesar 691 . Hal ini berarti pemberdayaan masyarakat desa berada pada interval kelas 630-750 atau Sangat Setuju (SS), sehingga menunjukkan bahwa aparatur pemeritah desa di kecamatan Talang Empat Kabupaten Bengkulu Tengah Telah memahami untuk penggunaan dana desa. Hal ini dapat dilihat dari jawaban yang diberikan oleh aparatur meskipun maish ada yang beranggappan bahwa pemberdayaan terhadap masyarakat belum cukup berarti. 
Pembinaan Masyarakat Desa

Tabel 4. Persepsi Responden Terhadap Pembinaan Masyarakat Desa

\begin{tabular}{|c|c|c|c|c|c|c|c|c|}
\hline \multirow{2}{*}{ No } & \multirow{2}{*}{ Pernyataan } & \multicolumn{5}{|c|}{ Tanggapan Responden } & \multirow{2}{*}{$\begin{array}{l}\text { Jumlah } \\
\text { Skor }\end{array}$} & \multirow{2}{*}{$\begin{array}{l}\text { Rata- } \\
\text { rata }\end{array}$} \\
\hline & & SS & $S$ & $\mathbf{R}$ & TS & STS & & \\
\hline 1. & $\begin{array}{l}\text { Tujuan Pembinaan terhadap masyarakat } \\
\text { untuk mencapai keinginan yang harapkan }\end{array}$ & 20 & 8 & 1 & 1 & 0 & 137 & 4,57 \\
\hline 2. & $\begin{array}{l}\text { Pembinaan berdasarkan pada nilai sosial } \\
\text { budaya masyarakat }\end{array}$ & 21 & 8 & 1 & 0 & 0 & 140 & 4,67 \\
\hline 3. & $\begin{array}{l}\text { Kegiatan pembinaan harus memiliki nilai } \\
\text { manfaat bagi masyarakat }\end{array}$ & 28 & 2 & 0 & 0 & 0 & 148 & 4,93 \\
\hline 4. & $\begin{array}{ll}\text { Kegiatan pembinaan } & \text { tidak menggangu } \\
\text { ketertiban masyarakat desa } & \end{array}$ & 23 & 6 & 1 & 0 & 0 & 142 & 4,73 \\
\hline 5. & $\begin{array}{l}\text { Pembinaan di tujukan untuk memberikan } \\
\text { bimbingan dan arahan ada masyarakat desa }\end{array}$ & 26 & 4 & 0 & 0 & 0 & 146 & 4,87 \\
\hline & Jumlah & 118 & 28 & 3 & 1 & 0 & 713 & 23,77 \\
\hline
\end{tabular}

Sumber : Hasil Kuesioner dan Diolah, 2016

Dari Tabel 4 diatas dapat diketahui bahwa jumlah skor jawaban yang diberikan oleh aparatur pemerintah desa terhadap penyelenggaraan pemerintah desa sebesar 713 atau nilai rata-rata 23,77. Hal ini menempatkan pembinaan masyarakat desa berada pada interval kelas 631 - 750 atau Sangat Setuju. Sehingga dari penjelasan tersebut dapat digambarkan grafik kontimum seperti pada gambar berikut ini :

Gambar 4. Grafik Pembinaan Masyarakat Desa

\begin{tabular}{|lr|l|l|l|l|l|l|}
\hline $\begin{array}{l}\text { Sangat } \\
\text { Setuju }\end{array}$ & Tidak & Tidak Setuju & Ragu-ragu & Setuju & \multicolumn{2}{|l|}{$\begin{array}{l}\text { Sangat } \\
\text { Setuju }\end{array}$} \\
\hline & & & & & & & \\
150 & 270 & 390 & 510 & 630 & 750 &
\end{tabular}

Sumber : Tabel 5 Diolah,2016

Berdasarkan dari tabel 4. dan gambar 4. dapat diketahui bahwa rating scale jawaban untuk variabel pembinaan masyarakat desa sebesar 713. Hal ini berarti pembinaan masyarakat desa berada pada interval kelas 630-750 (SS), sehingga menunjukkan bahwa persepsi aparatur pemerintah desa di Kecamatan Talang Empat Kabupaten Bengkulu Tengah dalam menggunakan dana desa telah memahami dan mengerti penggunaan dana desa.

\section{Pembahasan}

Tabel Keseluruhan Jawaban Responden Terhadap Penggunaan Dana Desa

Dari penjelasan sebelumnya maka dapat ditampilkan tabel keseluruhan jawaban dari setiap responden terhadap penggunaan dana desa adalah sebagai berikut ini:

Tabel 5. Persepsi Responden Terhadap Penggunaan Dana Desa

\begin{tabular}{|l|c|c|}
\hline \multicolumn{1}{|c|}{ Jenis Persepsi } & Jumlah Skor & Rata-rata \\
\hline Penyelenggaraan Pemerintah Desa & 718 & 23,93 \\
\hline Pembangunan desa & 706 & 23,53 \\
\hline Pemberdayaan Masyarakat Desa & 690 & 23 \\
\hline Pembinaan Masyarakat Desa & 713 & 23,77 \\
\hline
\end{tabular}

Sumber : Kuesioner Dan Diolah, 2016

Dari tabel 5. diatas dapat diketahui bahwa persepsi responden terhadap penggunan dana desa tertinggi di dapat oleh penyelenggaraan pemerintah desa dengan jumlah skor sebesar 718 atau nilai rata-rata 23,93. Sedangkan yang terendah yaitu diterima oleh pembinaan masyarakat desa dengan jumlah skor sebesar 690 atau nilai rata-rata 23, untuk pembinaan masyarakat desa jumlah skor sebesar 713 atau nilai ratarata 23,77 Sementara itu untuk pembangunan desa mendapatkan jumlah nilai skor sebesar 706 atau nilai rata-rata 23,53 . 


\section{Persepsi Aparatur Pemerintah Desa Terhadap Penyelenggaraan Pemerintah Desa}

Berdasarkan pada hasil penelitian yang telah di hitung dengan menggunakan rating scale dapat diketahui jika penyelenggaraan pemerintah desa merupakan faktor yang dapat mempengaruhi persepsi aparatur pemerintah desa terhadap dana desa di Kecamatan Talang Empat Kabupaten Bengkulu Tengah. Hal ini membuktikan bahwa dengan persepsi atau sikap aparatur pemerintah desa terhadap penyelenggaraan pemerintah desa baik maka akan dapat menjadi pertimbangan bagi aparatur pemerintah desa untuk menggunakan dana desa tersebut. Dari hasil perhitungan rating scale untuk pernyataan tentang penyelenggaraan pemerintah desa mendapatkan nilai berjumlah 718 atau sangat setuju. Dalam APBDes Desa Air Putih Kecamatan Talang Empat Kabupaten Bengkulu Tengah kegiatan, kegiatan penyeleggaraan pemerintah desa terdiri dari:

a. Belanja Pegawai yang terdiri dari penghasilan tetap kepala desa dan perangkat, tunjangan kepala desa dan perangkat tunjangan BPD dan anggota, honorarium PTKD dan tunjangan pengelola aset dan keuangan.

b. Kegiatan Operasional Kantor desa, terdiri atas belanja barang dan jasa, belanja modal, belanja musyarwarah pembuatan RPJMDes, RKDes, dan APBDes serta Kegiatan Operasional BPD.

Berdasarkan hal tersebut maka persepsi aparatur pemerintah desa terhadap penyelenggaraan pemerintah desa sudah sesuai dengan apa yang ada di dalam APBDes. Adapun rincian APBDes Desa Air Putih Kecamatan Talang Empat Kabupaten Bengkulu Tengah bidang penyelenggaraan pemerintah desa adalah sebagai berikut ini :

Tabel 6. Rincian Dana Kegiatan Penyelenggaraan Pemerintah Desa

\begin{tabular}{|c|c|c|c|}
\hline No & Kegiatan & Rincian Dana & Persentase \\
\hline 1. & Belanja Pegawai & Rp. 203.880.000 & \multirow{6}{*}{$22,33 \%$} \\
\hline & Pengahasilan tetap kepala desa dan perangkat & Rp. 144.600 .000 & \\
\hline & Tunjangan kepala desa dan perangkat & Rp. $\quad 6.480 .000$ & \\
\hline & Tunjangan BPD dan anggota & Rp. 31.920 .000 & \\
\hline & Honorarium PTPKD & Rp. 18.480 .000 & \\
\hline & Tunjangan Pengelolaan Aset dan Keuangan desa & $\begin{array}{ll}\text { Rp. } & 2.400 .000 \\
\end{array}$ & \\
\hline 2. & Kegiatan Operasional Kantor Desa & Rp. 86.912 .368 & \multirow{3}{*}{$9,52 \%$} \\
\hline & Belanja barang dan jasa & Rp. 65.980 .732 & \\
\hline & Belanja modal & Rp. 20.931 .636 & \\
\hline 3. & Belanja musyawarah pembuatan RKPDes dan APBDes & Rp. $\quad 7.440 .000$ & $0,82 \%$ \\
\hline 4. & Kegiatan operasional BPD & Rp. $\quad 3.000 .000$ & $0,33 \%$ \\
\hline & Jumlah Total & Rp. 301.232 .368 & $33,00 \%$ \\
\hline
\end{tabular}

Sumber : APBDes Desa Air Putih Kecamatan Talang Empat, 2016

Dari penjelasan diatas, maka dapat diketahui bahwa dana yang diperuntukan untuk bidang penyelenggaraan pemerintah desa yaitu sebesar Rp. 301.232.368 atau 33,00\%. Hal ini berarti dana pendapatan sebesar Rp. 909.706.183 terdapat 30\% yang dianggarkan untuk penyelenggaraan pemerintah desa. Sehingga memberikan kesimpulan bahwa persepsi aparatur pemerintah desa di Kecamatan Talang Empat Kabupaten Bengkulu Tengah sesuai dengan Anggaran Pendapatan Belanja Desa. Akan tetapi dalam pelaksanaannya aparatur pemerintah desa masih belum mengerti dan memahami tujuan dari penggunaan dana desa karena penyelenggaraan pemerintah desa dapat menggunakan dana lain yaitu melalui pendanaan yang lain dalam hal ini yaitu Alokasi Dana Desa (ADD). Hal ini dapat dilihat dari lampiran Anggaran Pendapatan Belanja Desa (APBDes) Desa Jum'at dimana disana masih menggunakan sebagian dana desa untuk melaksanakan kegiatan pada bidang penyelenggaraan pemerintah desa.

\section{Persepsi Aparatur Pemerintah Desa Terhadap Pembangunan Desa}

Berdasarkan pada hasil penelitian yang telah di hitung dengan menggunakan rating scale dapat diketahui jika pembangunan desa merupakan faktor yang dapat mempengaruhi persepsi aparatur pemerintah desa terhadap dana desa di Kecamatan Talang Empat Kabupaten Bengkulu Tengah. Hal ini membuktikan bahwa dengan pemberian persepsi atau sikap oleh aparatur pemerintah desa terhadap pembangunan desa baik maka akan dapat menjadi pertimbangan bagi aparatur pemerintah desa untuk menggunakan dana desa tersebut. Dari hasil perhitungan rating scale untuk pernyataan tentang pembangunan desa mendapatkan nilai berjumlah 706 (SS) atau sangat setuju. Dalam APBDes Desa Air Putih Kecamatan Talang Empat Kabupaten Bengkulu Tengah kegiatan, kegiatan pelaksanaan pembangunan desa terdiri dari :

a. Belanja Pegawai. 
b. Kegiatan pembangunan jalan desa, terdiri atas belanja barang dan jasa serta belanja modal.

c. Kegaiatan pengadaan saluran irigasi, terdiri atas belanja barang dan jasa serta belanja modal

d. Kegiatan Pengadaan sarana prasarana kesehatan, terdiri atas belanja barang dan jasa serta belanja modal.

Berdasarkan hal tersebut maka persepsi aparatur pemerintah desa terhadap penyelenggaraan pemerintah desa sudah sesuai dengan apa yang ada di dalam APBDes. Adapun rincian APBDes Desa Air Putih Kecamatan Talang Empat Kabupaten Bengkulu Tengah bidang penyelenggaraan pemerintah desa adalah sebagai berikut ini :

Tabel 7. Rincian Dana Kegiatan Pelaksanaan Pembangunan Desa

\begin{tabular}{|c|c|c|c|}
\hline No & Kegiatan & Rincian Dana & Persentase \\
\hline 1. & Belanja Pegawai & Rp. $\quad 4.500 .000$ & $0,50 \%$ \\
\hline \multirow[t]{3}{*}{2.} & Kegiatan pembangunan jalan & Rp. 177.289.898 & \multirow{3}{*}{$19,59 \%$} \\
\hline & Belanja barang dan jasa & $\begin{array}{ll}\text { Rp. } & 68.431 .898 \\
\end{array}$ & \\
\hline & Belanja modal & Rp. 108.858 .000 & \\
\hline \multirow[t]{3}{*}{3.} & Kegiatan pembangunan jalan & Rp. 70.320 .000 & \multirow{3}{*}{$7,77 \%$} \\
\hline & Belanja barang dan jasa & Rp. 15.300 .000 & \\
\hline & Belanja modal & Rp. $\quad 55.020 .000$ & \\
\hline \multirow[t]{3}{*}{4.} & Pengadaan saluran irigasi & Rp. 27.660 .000 & \multirow{3}{*}{$3,0 \%$} \\
\hline & Belanja barang dan jasa & $\begin{array}{ll}\text { Rp. } & 11.490 .000 \\
\end{array}$ & \\
\hline & Belanja modal & Rp. $\quad 16.170 .000$ & \\
\hline \multirow[t]{3}{*}{5.} & Kegiatan pengadaan sarana prasarana kesehatan & Rp. 197.095.815 & \multirow{3}{*}{$21,80 \%$} \\
\hline & Belanja barang dan jasa & Rp. $\quad 61.198 .815$ & \\
\hline & Belanja modal & Rp. 135.897 .000 & \\
\hline \multirow[t]{3}{*}{6.} & Kegiatan pengadaan sarana dan prasarana kesehatan & Rp. 39.000 .000 & \multirow[t]{3}{*}{$4,30 \%$} \\
\hline & Belanja barang dan jasa & $\begin{array}{ll}\text { Rp. } \quad 500.000 \\
\end{array}$ & \\
\hline & Belanja modal & Rp. 38.500 .000 & \\
\hline & Jumlah Total & Rp. 515.865.713 & $57,00 \%$ \\
\hline
\end{tabular}

Sumber : APBDes Desa Air Putih Kecamatan Talang Empat, 2016

Dari penjelasan diatas, maka dapat diketahui bahwa dana yang diperuntukan untuk bidang pelaksanaan pembangunan desa yaitu sebesar Rp. 515.865 .713 atau $57,00 \%$. Hal ini berarti dana pendapatan sebesar Rp. 909.706.183 terdapat 57\% yang dianggarkan untuk penyelenggaraan pemerintah desa. Sehingga memberikan kesimpulan bahwa faktor pembangunan desa merupakan faktor yang mempengaruhi aparatur pemerintah desa yang dapat di jadikan sebagai bahan dasar untuk menggunakan dana desa. Sehingga persepsi aparatur pemerintah desa terhadap pelaksanaan pembangunan desa telah sesuai dengan Anggaran Pendapatan Belanja Desa.

\section{Persepsi Aparatur Pemerintah Desa Terhadap Pemberdayaan Masyarakat Desa}

Berdasarkan pada hasil penelitian yang telah di hitung dengan menggunakan rating scale dapat diketahui jika pemberdayaan masyarakat desa merupakan faktor yang dapat mempengaruhi persepsi aparatur pemerintah desa terhadap dana desa di Kecamatan Talang Empat Kabupaten Bengkulu Tengah. Hal ini membuktikan bahwa dengan persepsi atau sikap aparatur pemerintah desa terhadap pemberdayaan masyarakat desa baik maka akan dapat menjadi pertimbangan bagi aparatur pemerintah desa untuk menggunakan dana desa tersebut. Dari hasil perhitungan rating scale untuk pernyataan tentang pemberdayaan masyarakat desa mendapatkan nilai skor berjumlah 690 (SS) atau sangat setuju. Hal ini berarti bahwa aparatur pemerintah desa menyetujui dan memahami tentang penggunaan dana desa. Dalam APBDes Desa Air Putih Kecamatan Talang Empat Kabupaten Bengkulu Tengah, kegiatan pemberdayaan masyarakat desa memiliki beberapa kegiatan. Dimana kegiatan-kegiatan tersebut memiliki rincian biaya. Dana kegiatan tersebut terdiri dari :

a. Kegiatan pelatihan kepala desa dan perangkat, terdiri atas belanja barang dan jasa .

b. Kegiatan peningkatan kapasitas masyarakat.

c. Pelatihan pengurus badan usaha milik desa, terdiri atas belanja barang dan jasa dan.

d. Bidang tak terduga.

Berdasarkan hal tersebut maka persepsi aparatur pemerintah desa terhadap pemberdayaan masyarakat desa sudah sesuai dengan apa yang ada di dalam Anggaran Pendapatan Belanja Desa (APBDes). Adapun rincian APBDes Desa Air Putih Kecamatan Talang Empat Kabupaten Bengkulu Tengah pada bidang pemberdayaan masyarakat desa dapat di ditampilkan sebagai berikut ini : 
Tabel 8. Rincian Dana Kegiatan Pemberdayaan Masyarakat Desa

\begin{tabular}{|l|l|l|c|}
\hline No & \multicolumn{1}{|c|}{ Kegiatan } & \multicolumn{1}{c}{ Rincian Dana } & Persentase \\
\hline 1. & Kegiatan pelatihan kepala desa dan perangkat desa & Rp. $\mathbf{7 . 5 1 3 . 0 0 0}$ & \multirow{2}{*}{$\mathbf{0 , 8 3 \%}$} \\
\hline & Belanja barang dan jasa & Rp. 7.513 .000 & \\
\cline { 1 - 3 } 2. & Kegiatan peningkatan kapasitas masyarakat & Rp. $\mathbf{1 0 . 5 5 0 . 0 0 0}$ & $\mathbf{1 , 1 6 \%}$ \\
\hline 3. & Pelatihan pengurus badan usaha milik desa & Rp. $\mathbf{9 . 1 8 5 . 0 5 1}$ & \multirow{2}{*}{$\mathbf{1 , 0 1}$} \\
\cline { 1 - 3 } & Belanja barang dan jasa & Rp. 9.185 .051 & $3,00 \%$ \\
\hline
\end{tabular}

Sumber : APBDes Desa Air Putih Kecamatan Talang Empat, 2016

Dari penjelasan diatas, maka dapat diketahui bahwa dana yang diperuntukan untuk bidang pemberdayaan masyarakat desa yaitu sebesar Rp. 27.248 .051 atau 3,00\%. Hal ini berarti dana pendapatan sebesar Rp. 909.706.183 terdapat 3\% yang dianggarkan untuk pemberdayaan masyarakat desa. Sehingga memberikan kesimpulan bahwa faktor pemberdayaan masyarakat desa merupakan faktor yang dapat mempengaruhi aparatur pemerintah desa dan sesuai dengan APBDes. Seharusnya dana desa yang dianggarkan untuk kegiatan pemberdayaan masyarakat desa lebih banyak dari yang ada saaat ini. Hal ini dikarenakan pemberdayaaan masyarakat berisi dengan kegiatan pelatihan dan pemberian pengetahuan yang mana kegiatan-kegiatan tersebut bersifat memajukan keahlian masyarakat. Akan tetapi disini dapat dilihat bahwa dana yang di kucurkan untuk kegiatan peningkatan kapasitas masyarakat masih terlalu kecil. Sehinggga dengan kecilnya biaya yang dikeluarkan dalam melakukan pemberdayaan masyarakat desa dan BUMDes maka harapan yang ingin dicapai belum dapat terwujud. Untuk mencapai harapan tersebut diperlukan pemikiran ulang supaya nantinya masyarakat desa dapat lebih sejahtera kembali. Dan dari hal ini aparatur pemerintah desa belum sepenuhnya memahami kegiatan yang harus diutamakan dalam menggunakan aggaran dana desa.

\section{Persepsi Aparatur Pemerintah Desa Terhadap Pembinaan Masyarakat Desa}

Berdasarkan pada hasil penelitian yang telah di hitung dengan menggunakan rating scale dapat diketahui jika pembinaan masyarakat desa merupakan faktor yang harus dipahami aparatur pemerintah desa terhadap dana desa di Kecamatan Talang Empat Kabupaten Bengkulu Tengah. Hal ini membuktikan bahwa dengan persepsi atau sikap aparatur pemerintah desa terhadap pembinaan masyarakat desa mengerti maka akan dapat menjadi pertimbangan bagi aparatur pemerintah desa untuk menggunakan dana desa tersebut. Dari hasil perhitungan rating scale untuk pernyataan tentang pembinaan masyarakat desa mendapatkan nilai berjumlah 713 (SS) atau sangat setuju. Hal ini berarti bahwa aparatur pemerintah desa menyetujui Anggaran Pendapatan Belanja Desa (APBDes) diperuntukkan untuk kegiatan pembinaan masyarakat desa. Dalam APBDes Desa Air Putih Kecamatan Talang Empat Kabupaten Bengkulu Tengah, kegiatan pembinaan masyarakat desa terdiri dari :

a. Kegiatan pembinaan keamanan dan ketertiban, terdiri dari belanja barang dan jasa.

b. Kegiatan pembinaan pemuda dan olahraga, terdiri atas belanja barang dan jasa.

c. Kegiatan pembinaan organisasi perempuan/PKK, terdiri atas belanja barang dan jasa.

d. Kegiatan pembinaan kesenian dan sosial budaya, terdiri dari belanja barag dan jasa.

e. Kegiatan pembinaan kerukunan umat beragama, terdiri dari insentif.

f. Kegiatan pembinaan lembaga adat, terdiri dari belanja barang dan jasa.

g. Kegiataan pembinaan pendidikan anak usia dini, terdiri dari belanja barang dan jasa.

h. Kegiatan pembinaan posyandu, terdiri dari belanja barang dan jasa.

Berdasarkan hal tersebut maka persepsi aparatur pemerintah desa terhadap pembinaan masyarakat desa sudah sesuai dengan APBDes yang telah dianggarkan. Adapun rincian APBDes Desa Air Putih Kecamatan Talang Empat Kabupaten Bengkulu Tengah dalam bidang pembinaan masyarakat desa terdapat beberapa kegiatan. Dimana kegiatan tersebut memiliki rincian dana yang berbeda-beda meskipun ada beberapa kegiatan yang tidak dapat dianggarkan. Berikut ini rincian dana kegiatan pembinaan masyarakat desa. 
Tabel 9. Rincian Dana Kegiatan Pembinaan Masyarakat Desa

\begin{tabular}{|c|c|c|c|}
\hline No & Kegiatan & Rincian Dana & Persentase \\
\hline \multirow[t]{2}{*}{1.} & Kegiatan pembinaan pemuda dan olahraga & Rp. 1.300 .000 & \multirow{2}{*}{$0,13 \%$} \\
\hline & Belanja barang dan jasa & Rp.1.300.000 & \\
\hline \multirow{2}{*}{2.} & Kegiatan pembinaan organisasi perempuan/ PKK & Rp.3.000.000 & \multirow{2}{*}{$0,30 \%$} \\
\hline & Belanja barang dan jasa & Rp.3.000.000 & \\
\hline \multirow[t]{2}{*}{3.} & Kegiatan pembinaan kerukunan umat beragama & Rp.18.600.000 & \multirow{2}{*}{$1,85 \%$} \\
\hline & Insentif perangkat syara' & Rp.18.600.000 & \\
\hline \multirow[t]{2}{*}{4.} & Kegiatan pembinaan lembaga adat & Rp. 1.800.000 & \multirow{2}{*}{$0,17 \%$} \\
\hline & Belanja barang dan jasa & Rp. 1.800 .000 & \\
\hline \multirow[t]{2}{*}{5.} & Kegiatan pembinaan pendidikan anak usia dini & Rp. 9.600.000 & \multirow{2}{*}{$0,95 \%$} \\
\hline & Belanja barang dan jasa & Rp. 9.600 .000 & \\
\hline \multirow[t]{2}{*}{6.} & Kegiatan pembinaan posyandu & Rp. 6.000.000 & \multirow{2}{*}{$0,60 \%$} \\
\hline & Belanja barang dan jasa & Rp. 6.000 .000 & \\
\hline & Jumlah Total & Rp. 40.300.000 & $4,00 \%$ \\
\hline
\end{tabular}

Sumber : APBDes Desa Air Putih Kecamatan Talang Empat, 2016

Dari penjelasan diatas, maka dapat diketahui bahwa dana yang diperuntukan untuk bidang pembinaan masyarakat desa yaitu sebesar Rp. 40.300 .000 atau 4,00\%. Hal ini berarti dana pendapatan sebesar Rp. 909.706 .183 terdapat 4\% yang dianggarkan untuk pembinaan masyarakat desa. Sehingga memberikan kesimpulan bahwa persepsi aparatur pemerintah desa sangat setuju terhadap pembinaan masyarakat desa serta telah sesuai dengan APBDes, Akan tetapi didalam pelaksanaannya masih belum sepenuhnya memahami dan mengerti cara penggunaannya. Dimana pembinaan masyarakat desa menggunakan Alokasi Dana Desa sehingga terdapat ketidaksamaan antara persepsi dengan pelaksanaannya.

Sementara itu dari semua kegiatan tersebut terdapat surplus sebesar Rp. 25.060.051 dimana dana tersebut selanjutnya dikeluarkan pada bagian pembiayaan untuk rekening pengeluran pembiayaan BUMDes. Adapun rincian tersebut adalah sebagai berikut ini :

Tabel 10. Rincian Dana Pembiayaan

\begin{tabular}{|l|l|l|l|}
\hline No & Kegiatan & Rincian Dana & Persentase \\
\hline 1. & Pembiayaan & - & - \\
\hline & Pengeluaran Pembiayaan & - & - \\
\hline & Pembentukan Dana Cadangan & - & - \\
\hline & Penyertaan Modal Desa & - & - \\
\hline & BUMDes & Rp. 25.0600 .051 & $3,00 \%$ \\
\hline
\end{tabular}

Sumber : APBDes Desa Air Putih Kecamatan Talang Empat, 2016

Dari tabel diatas dapat diketahui bahwa dana pembiayaan untuk BUMDes sebesar Rp. 25.060.051 atau 3,00\%. Sehinggga total keseluruhan dana yang berjumlah Rp. 909.706 .183 tersebut diperuntukan unutk kegiatan pemerintahan desa dan telah dipeuntukan untuk masing-masing bidang dengan mencapai persentase akhir yaitu $100 \%$.

\section{KESIMPULAN}

1. Nilai Rating Scale untuk persepsi aparatur pemerintah desa terhadap penyelenggaraan pemerintah desa sebesar 718 dan berada pada interval kelas 631 - 750, hal ini berarti bahwa aparatur pemerintah desa di Kecamatan Talag Empat Kabupaten Bengkulu Tengah sangat setuju dengan bidang kegiatan penyelenggaraan pemerintah desa dan sudah sesuai dengan Anggaran Pendapatan Belanja Desa (APBDes) .

2. Nilai Rating Scale untuk persepsi aparatur pemerintah desa terhadap pembangunan desa sebesar 706 dan berada pada interval kelas 631 - 750, hal ini berarti bahwa aparatur pemerintah desa di Kecamatan Talag Empat Kabupaten Bengkulu Tengah sangat setuju dengan bidang kegiatan pelaksanaan pembangunan desa sehingga dapat membangun infrastruktur desa yang belum ada dan sudah sesuai dengan Anggaran Pendapatan Belanja Desa (APBDes) .

3. Nilai Rating Scale untuk persepsi aparatur pemerintah desa terhadap penyelenggaraan pemerintah desa sebesar 690 dan berada pada interval kelas 631 - 750 atau Sangat Setuju ( SS), hal ini berarti aparatur pemerintah desa di Kecamatan Talag Empat Kabupaten Bengkulu Tengah sangat setuju 
dengan bidang kegiatan pemberdayaan masyarakat desa dan sudah sesuai dengan Anggaran Pendapatan Belanja Desa (APBDes).

4. Nilai Rating Scale untuk persepsi aparatur pemerintah desa terhadap pembinaan masyarakat desa sebesar 713 dan berada pada interval kelas 631 - 750 atau Sangat Setuju ( SS), hal ini berarti aparatur pemerintah desa di Kecamatan Talag Empat Kabupaten Bengkulu Tengah sangat setuju dengan bidang kegiatan pembinaan masyarakat desa dan sudah sesuai dengan Anggaran Pendapatan Belanja Desa (APBDes).

\section{SARAN}

1. Dalam pembangunan diharapkan masyarakat lebih diikut sertakan baik dalam pelaksanaan maupun pengawasan.

2. Tingkat Transparansi APBDes sebaiknya diperbaiki.

3. Dalam APBDes seharusnya desa memiliki PAD tersendiri agar ketika dana transfer tertunda kegiatan operasional tetap berjalan.

4. Dalam pembangunan sebaiknya menggunakan sumber daya yang ada di desa.

5. Sebaiknya pemberdayaan terhadap masyarkat lebih di galakkan agar terjadi perkembangan di tengah masyarkat.

\section{DAFTAR PUSTAKA}

Abdullah, Rozali.2011. Pelaksanaan Otonomi Luas Dengan Pemilihan Kepala Daerah Secara Langsung. Jakarta: PT. Raja Grafindo

Hanif, Nurcholis 2011. Pertumbuhan dan penyelenggaraan pemerintahan desa. Jakarta: ERLANGGA

Kamus Besar Bahasa Indonesia.2007. Jakarta

Mardalis.2009. Metode Penelitian Suatu Pendekatan Proposal. Jakarta: Bumi Aksara

Mona. 2015. Undang-Undang Desa Kelurahan Dan Kecamatan. Yogyakarta: Pustaka Mahardika

Moleong, Lexy J.2014. Metode Penelitian Kualitatif. Bandung: PT. Remaja Rosdakarya

Mustakim, Mochammad Zaini.2015. Kepemimpinan Desa. Jakarta: Kementerian Desa, Pembangunan Daerah Tertinggal, dan Transmigrasi Republik Indonesia

Rakhmat, Jalaludin.2007. Psikologi Komunikasi. Bandung: PT. Remaja Rosdakarya

Pieter, Herri Zan \& Lubis, Namora Lumongga.2010. Pengantar Psikologi Dalam Keperawatan. Jakarta: Prenada Media

Peraturan Menteri Keuangan Nomor 49-PMK.07/2016

Prabawa, Akbar.2015. "Pengelolaan Alokasi Dana Desa Dalam PembangunanDi Desa Loa Lepu Kecamatan Tenggarong SeberangKabupaten Kutai Kartanegara". Jurnal tidak diterbitkan. Universitas Mulawarman

Soleh, Chabib dan Heru Rochansjah.2015. Pengelolaan Keuangan Desa. Bandung: Fokus Media

Sugiyono.2012. Metode Penelitian Bisnis. Bandung: Alfabeta, CV.

Subroto, Agus.2009. Akuntabilitas Pengelolaan Dana Desa (Studi Kasus Pengelolaan Alokasi Dana Desa Di Desa-desa Dalam Wilayah Kecamatan Tlogomulyo Kaupaten Temanggung Tahun 2008). Universitas Diponegoro Semarang

Undang-Undang Desa Kelurahan Dan Kecamatan

Undang-Undang Nomor 06 Tahun 2014 Tentang Desa Dan Peraturan Terkait

Widjaja, Haw.2006. Otonomi Desa Merupakan Ekonomiyang Asli, Bulat dan Utuh. Jakarta: PT. Raja Grafindo

Widjaja, Haw.2006. Penyelenggaraan Otonomi Daerah Di Indonesia Dalam Rangka Sosialisasi UU No. 32 Tahun 2004 Tentang Pemerintah Desa. Jakarta: PT. Raja Grafindo

www.bengkulutengahkab.go.id

Yustisia, Tim Visi.2016. Pedoman Resmi Petunjuk Pelaksanaan Dana Desa. Jakarta: Visimedia

Zarkasi, Muslichah.2006. Psikologi Manajemen. Jakarta: PT. Gelora Aksara Pratama 